\title{
The Informal Sector in Developing Countries
}

\author{
Output, Assets and Employment
}

Sangeeta Pratap ${ }^{1}$ and Erwan Quintin ${ }^{2}$

November 2006

\begin{abstract}
This study documents four key facts about informal economic activities: (1) the size of the informal sector varies greatly across nations; (2) this size is strongly correlated with economic development, the tax burden, and the rule of law; (3) the informal sector emphasizes small-scale, self-financed and unskilled labour intensive economic activities; and (4), while financial markets are generally segmented along formal/informal lines in developing nations there is no compelling evidence that this is true for labour markets. We review the existing theoretical literature on the informal sector and describe a simple model with a tradeoff between tax evasion and access to formal sources of outside finance which is consistent with much of the existing evidence. Finally, the study discusses the challenges associated with measuring informal sector assets.
\end{abstract}

Keywords: segmented labour markets, informal sector JEL classification: O17, L23, E24

Copyright @ C UNU-WIDER 2006

${ }^{1}$ Hunter College and Graduate Center City University of New York; ${ }^{2}$ Federal Reserve Bank of Dallas

This study has been prepared within the UNU-WIDER project on Personal Assets from a Global Perspective, directed by Jim Davies.

UNU-WIDER acknowledges with thanks the financial contributions to its research programme by the governments of Denmark (Royal Ministry of Foreign Affairs), Finland (Ministry for Foreign Affairs), Norway (Royal Ministry of Foreign Affairs), Sweden (Swedish International Development Cooperation Agency - Sida) and the United Kingdom (Department for International Development). 


\section{Acknowledgements}

The views expressed in this study are those of the authors and do not necessarily reflect the position of the Federal Reserve Bank of Dallas or the Federal Reserve System. We would like to thank Jim Davies and Basudeb Guha-Khasnobis for many helpful comments and suggestions.

The World Institute for Development Economics Research (WIDER) was established by the United Nations University (UNU) as its first research and training centre and started work in Helsinki, Finland in 1985. The Institute undertakes applied research and policy analysis on structural changes affecting the developing and transitional economies, provides a forum for the advocacy of policies leading to robust, equitable and environmentally sustainable growth, and promotes capacity strengthening and training in the field of economic and social policy making. Work is carried out by staff researchers and visiting scholars in Helsinki and through networks of collabourating scholars and institutions around the world. www.wider.unu.edu publications@wider.unu.edu

UNU World Institute for Development Economics Research (UNU-WIDER)

Katajanokanlaituri 6 B, 00160 Helsinki, Finland

Camera-ready typescript prepared by Lorraine Telfer-Taivainen at UNU-WIDER

The views expressed in this publication are those of the author(s). Publication does not imply endorsement by the Institute or the United Nations University, nor by the programme/project sponsors, of any of the views expressed. 


\section{Introduction}

A distinguishing feature of developing economies is the importance of untaxed, unregulated activities. According to existing estimates, it is not unusual for the informal sector to account for over half of GDP and employment in low-income nations. The prevalence of informal activities in these nations is a natural response to burdensome regulatory and tax environments. However, it comes at a cost. Small tax bases constrain fiscal authorities to raise revenues through inefficient means and to delay necessary investments in infrastructure and education. Furthermore, resources are not likely to be directed to their most efficient uses if production is carried out in an environment where formal mechanisms of contract enforcement and dispute resolution are not available. Governments in developing nations resort to a variety of policies to try and bring more economic units into the tax-paying fold. These range from sporadic crackdowns on undeclared economic activities, to subsidies and tax breaks for firms that agree to register legally and maintain legitimate tax accounting practices. Understanding the intended and unintended effects of these policies (and their often limited success) is an important area of research. This requires models that are consistent with the existing evidence on the nature and determinants of informal economic activities.

Our first objective in this study is to document a set of robust empirical regularities with which a satisfactory model of the informal sector should be consistent. These regularities include a strong correlation between institutional quality, the tax burden and the size of the informal sector, even among nations at similar stages of economic development. They also include marked differences in the distribution of employee and employer characteristics across sectors. Specifically, the informal sector emphasizes self-financed, under-capitalized, small-scale, unskilled-labour intensive production.

An empirical issue over which there is much less consensus is whether or not labour markets are segmented along formal/informal lines in developing nations. While all evidence indicates that, on average, formal wages are higher than informal wages, this average earnings differential could simply reflect the fact that formal workers tend to be more educated and more experienced than their informally employed counterparts. Although many papers argue that a formal sector premium remains after controlling for observable employer and employee characteristics, it is well-known that standard segmentation tests are weak and produce results that are sensitive to the choice of econometric techniques. ${ }^{1}$ Overall, Maloney (1999) concludes that compelling evidence that labour markets are dualistic in developing countries has yet to be produced. We point out in this chapter that the debate over segmentation has important implications for the evaluation of pro-development policies. Our view is that until the debate is resolved, the policy implications of models based on the assumption that labour markets

1 See Heckman and Hotz (1986). 
are segmented should be interpreted with caution and compared to the prescriptions that emanate from competitive models.

Our second objective is to evaluate the extent to which current models of the informal sector are consistent with the existing empirical evidence. Early work on the informal sector emphasized barriers to entry into the formal sector for workers as the explanation for the existence of large informal sectors in many low-income countries. In contrast, in the recent literature, large informal sectors arise as the optimal response to burdensome institutional environments. In those models, direct subsidies to formal employment are poor substitutes for improvements in institutional quality. We describe a static model that contains the key ingredients of most modern models of the informal sector and show that it provides potential explanations for much of what we know about the informal sector. Furthermore, because recent work adopts a general equilibrium approach, it is possible to analyze the effects of various public policies on welfare, output and productivity.

Our final objective is to discuss the difficulties associated with measuring informal sector wealth. The empirical evidence suggests that a large fraction of capital formation takes place in the informal sector. By their very nature, informal assets are difficult to inventory. Given the difficulties inherent to recording hidden economic activities, the large size of informal sectors in many nations makes measures of wealth inequality across households and across countries unreliable. The only solution lies in the continued improvement of national accounting practices worldwide. These measurement issues have important consequences for policy. As de Soto (2000) explains, formal and informal assets are not comparable. Because informal assets seldom carry proper titles, they cannot be used as collateral for formal loans which implies that many profitable investment opportunities, hence opportunities to build wealth, are left untapped in the informal sector. These observations lead de Soto to conclude that formalizing property rights is the key to giving the poor better access to credit. This view is controversial2 but it is clear that properly accounting for informal wealth will help improve the design of development policies.

The study is organized as follows. Section 2 surveys the evidence on the size and determinants of the informal sector and the characteristics of formal and informal production. In section 3 we discuss theories of informal sector activities and the extent to which they are consistent with the empirical characteristics of informal activity. The fourth section sketches a model of informal and formal activity that is consistent with the existing evidence. We discuss the challenges associated with measuring informal sector assets in section 5 , and section 6 concludes.

\footnotetext{
2 See Woodruff (2001) for a discussion.
} 


\section{The facts}

This section provides a survey of the existing evidence on the importance, the characteristics and the determinants of informal economic activities. As we shall see, empirical studies in this area tend to employ very different methodologies, in part because they rely on different practical definitions of informal activities. Despite these methodological differences, the empirical literature has unearthed a number of robust characteristics of informal sector production.

\subsection{Definitions of informal activities}

In the context of its World Employment Programme, the International Labour Organization (ILO) sponsored several surveys of labour markets in developing nations in the early 1970s. The findings of these surveys, particularly those associated with the Kenya mission in 1972 (see ILO 1972), stress the importance of unregulated, informal economic activities. The ILO elected to define the informal sector as enterprises with all or most characteristics in a list that includes 'family ownership ... small scale of operations ... labour-intensive methods...'.

Weeks (1975) chooses instead to define formal firms as firms that are '...recognized, nurtured and regulated by the state'. Hart (1973) defines the formal sector as wage earners as opposed to self-employed workers. Mazumdar (1975) takes a similar approach but bases his distinction between informal and formal workers on whether or not they receive protection from the government and/or trade unions. This definition illustrates the dualistic (or segmented) view of labour markets in developing nations that originated with Lewis (1954). According to this view, the 'wage-level and working conditions in the [formal] sector are not available, in general, to the job seekers in the market unless they manage to cross the barrier of entry somehow' (Mazumdar 1975).

These early definitions of informality were quickly criticized for being ambiguous (Sethuraman 1981) or simplistic (Bromley 1978). Recognizing the difficulty of providing a strict, universal definition of informality, Castells et al. (1989) offer the following context-specific definition: informal activities are a 'process of incomegeneration' that is 'unregulated by the institutions of society, in a legal and social environment in which similar activities are regulated'. The formal sector, in this broad sense, includes all production establishments that fail to comply with government regulations such as taxes and the labour code and all workers who fail to receive government-mandated benefits or are paid below the minimum wage. Many recent investigations of the informal sector rely on practical implementations of this view that reflect the constraints imposed by data availability.

\subsection{Measurement issues}

Given the nature of informal activities, measuring the size of the informal sector is a difficult task. A variety of methods have been used to construct estimates. This section 
reviews some of the commonly used methods. It draws heavily on Schneider and Enste (2000) and the references contained therein.

Direct approaches to measuring the size of the informal sector rely on survey data. For instance, standard household surveys provide a good estimate of the fraction of workers who fail to receive the benefits which labour law mandates in a given nation (see e.g. Pratap and Quintin 2006). Some surveys directly question households about their activities, both declared and undeclared. Clearly, the quality of the resulting estimates depends crucially on the reliability of responses. Data from fiscal audits can also provide estimates of the magnitude of undeclared income in a given nation, after correcting for the fact that taxpayers selected for audit are a biased sample.

An alternative approach is to estimate the size of the informal sector indirectly using macroeconomic variables. One estimate of the importance of undeclared activities is the gap between GDP measured according the income approach and GDP measured according to the expenditure approach. A second approach (known as the currencydemand method) attributes the fraction of currency demand which is not explained by a standard money demand equation to the informal sector. 3 A third indirect approach uses electricity consumption data to obtain an estimate of total economic activity, from which one can subtract official measures of economic activity to produce an estimate of unofficial activity. This method is often referred to as the physical input method. In addition to assuming that the ratio of electricity use to economic activity is relatively stable, this approach requires reliable electricity consumption data. Finally, the model approach (often called the Multiple Indicator, Multiple Cause or MIMIC model) tries to estimate the size of the informal sector in the context of a flexible statistical model. Typically these models have two components: an equation that specifies the informal sector as a latent endogenous variable which is causally related to several factors (such as tax burdens, labour market restrictions, efficiency of government institutions), and a second equation where the informal sector determines a set of endogenous indicators (such as tax evasion, monetized transactions, official labour market participation rates etc.) Identification in these models comes from restrictions on structural parameter values and the variance covariance matrix of the error terms.

As we discuss in Section 5, in order to produce all-inclusive measures of economic activities, national accountants worldwide supplement these standard measurement methods with other available data on 'hidden' economic activity in various industries, most notably data on material use. However, for the purpose of studying the determinants of informal activity, macroeconomic models have the advantage of

\footnotetext{
3 The premise here is that cash is the principal medium of exchange and plays an important role as store of value in the informal sector. Arguments to support this premise include the fact that a share of informal activities is illegal, and the fact that households who operate in the informal sector have limited access to banking services. See Thomas (1992: chapter 7) for a discussion.
} 
applying uniform procedures to all countries making cross-country comparisons possible.

While estimates of the output and employment size of the informal sector are now available for a large cross-section of nations, estimates of the asset size of the informal sector (of the fraction of physical capital that is employed in the informal sector, for instance) are almost non-existent. One exception is de Soto (2000) who provides rough estimates of informal wealth for a few nations. The lack of informal wealth estimates is not surprising given the obvious difficulties associated with tracking informal investment. Section 5 discusses some of issues associated with measuring assets in the informal sector.

\subsection{Size of the informal sector}

All the measurement approaches we have described are based on strong, often unverifiable assumptions, and one should therefore focus on results that are not sensitive to particular methodological choices. In their survey article, Schneider and Enste (2000) list a range of existing estimates of the size of the informal sector for a large cross-section of countries. The range of estimates available for each country is wide in some cases, but the correlation across estimates obtained from different methods is, with a few exceptions, reasonably strong.

Figure 1: Economic development and informality

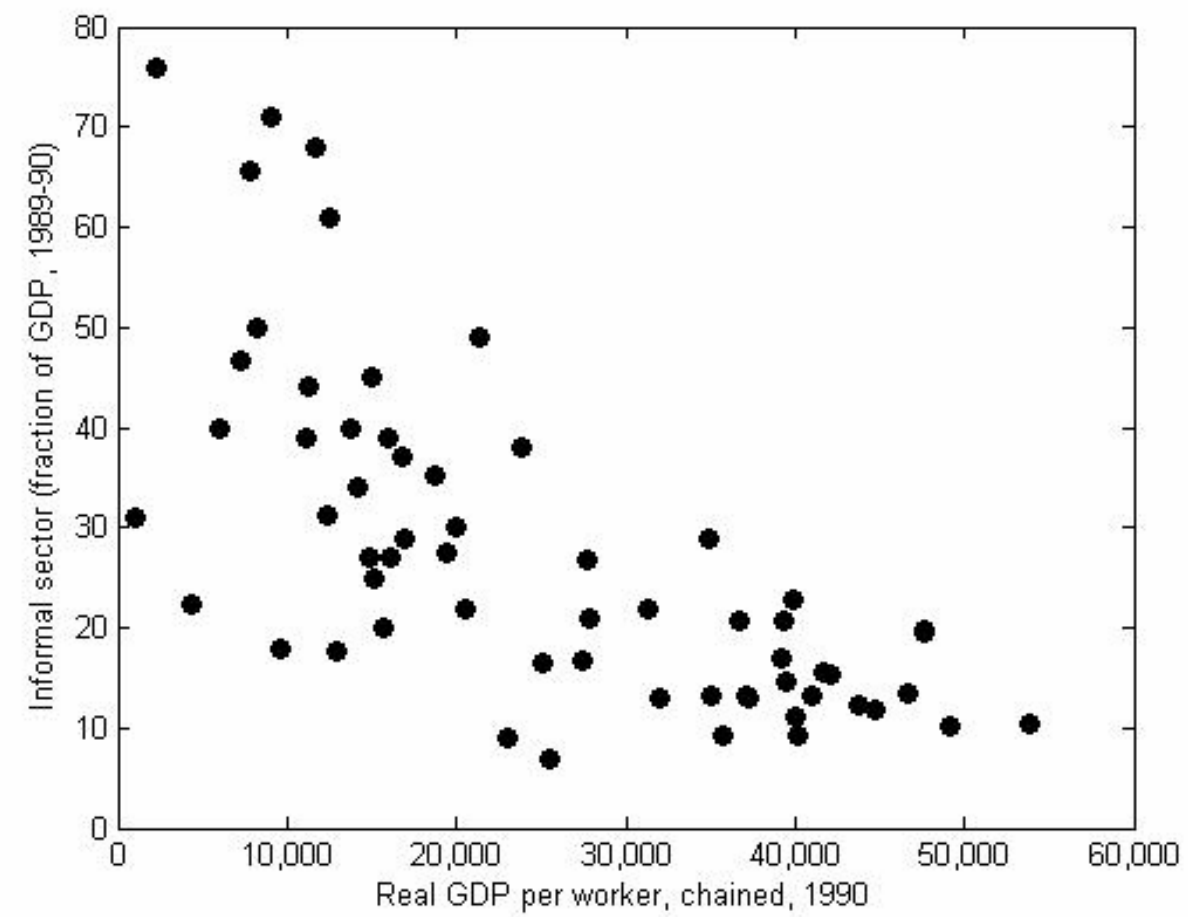

Source: Penn World Tables (mark 6.1) and Schneider and Enste (2000). Real GDP per worker is in \$US chained around 1990. The size of the informal sector is measured using the physical input method for most countries, and the currency demand approach for a few countries. 
Figure 1 plots the output size of the informal sector (measured using the physical input method) in 1989-90 against real GDP per worker for all countries for which Schneider and Enste (2000) provide data. The figure illustrates several well-established facts. Most notably, the importance of informal economic activities varies greatly across countries and it is highly correlated with the level of economic development. Informal output represents 10 to 15 per cent of official GDP in most developed nations, compared to 25 to 80 per cent in most developing nations. The figure also shows that the size of the informal sector varies greatly even among nations at similar stages of economic development. This begs a natural question: do nations with large informal sectors share distinguishing features other than a typically low level of income per capita? In principle, the variance in the importance of informal activities among nations at a similar income level could simply be the result of the noise inherent to the methods employed to produce those estimates. It turns out however that the size of the informal sector is strongly correlated with several country-specific features.

Using a cross section of Latin American countries in the early 1990s, Loayza (1996) finds that the size of the informal sector depends positively on proxies for the tax burden and labour market restrictions. The size of the informal sector is also negatively related to a proxy for the quality of government institutions which reflects the quality of bureaucracy, corruption in government and the rule of law. Johnson et al. (1998) obtain similar results with a sample of 49 countries that include Latin America, the OECD, and the former Soviet Union in the 1990s. They find that the unofficial economy tends to be small in countries with a business friendly regulatory regime and a comparatively light tax burden. They also find that indices that proxy for the security of property rights and the quality of the legal system account for a significant fraction of the cross-country variance in the size of the informal sector, and that corruption indices are negatively related to the size of the informal sector. Botero et al. (2003) find that heavier regulation of labour is associated with a larger unofficial economy in a cross sample of 85 countries.

These and other studies have uncovered a clear pattern in the cross-country evidence. Nations with poorly functioning institutions, a heavy tax burden and high levels of corruption tend to have large informal sectors. This constitutes strong evidence in favour of models where employers optimally weigh the costs and benefits of operating formally. As de Soto (1989) suggests, informality is a natural response to a burdensome regulatory environment. As we shall see in Section 3, most modern models of the informal sector are founded on this appealing intuition.

\subsection{Formal and informal firms}

Formal and informal firms operate under very different constraints. Most obviously, formal employers bear a number of regulatory costs that unregistered firms can typically avoid. These costs include licenses, bureaucratic approvals, bribes and other fees. De Soto (1989) estimated that setting up a legitimate business in Lima, Peru required a 
10 month waiting period (estimated to cost over a thousand dollars in lost profits) and about US\$200 in fees. The same operation took 3.5 hours in Florida and four hours in New York (Chickering and Salahdine 1991). Djankov et al. (2002) estimate these costs of entry in 85 countries and find that they range from 2.63 per cent of per capita GDP in Canada to 463 per cent of per capita GDP in the Dominican Republic.

Perhaps the most important cost borne by producers who choose to enter the formal sector is that they become subject to profit and payroll taxes. Tax rates are often set high in developing nations since governments are constrained to rely on a very small tax base. Other regulations such as environmental and zoning rules and restrictions in the use of imported inputs are also important in some countries. Finally, formal producers must typically comply with the stipulations of the labour code including minimum wage restrictions, severance payments, and social security requirements.

On the other hand, operating legally gives employers better access to public goods such as formal contract enforcement mechanisms. It is difficult to enter into enforceable, verifiable business arrangements with an economic unit that does not exist legally, does not maintain credible accounting practices and often lacks a clear title to the assets it owns. Claiming collateral in the event of default is therefore difficult, if not impossible. As a result, informal producers must operate with little or no outside finance. For instance, using survey data from Lima, Peru, Wendorff (1985) calculates that almost 80 per cent of the funds used by informal producers (producers who operate below certain employment thresholds that vary across sectors) are self-financed and that informal (non-bank) sources of finance account for most of the remaining capital. According to his calculations, bank loans play a negligible role in informal sector production. Furthermore, the loans that informal producers obtain from informal sources are small, often granted on a very short-term basis, and carry exorbitant interest rates. 4

Not surprisingly then, informal production tends to be much more labour-intensive than formal production. Paredes Cruzatt (1987) calculates that half of informally employed workers in Lima, Peru, in 1983 operated with less than US\$500 worth of capital while over 90 per cent of formally employed workers operated with over US\$6,000 worth of capital. Soderbom and Teal (2000) discuss data from four sub-Saharan African nations 5 that illustrate the heterogeneity in capital intensity across firms in developing countries. Their numbers suggest that manufacturing firms with more than 100 employees operate on average with three to four times more physical capital per employee than firms with fewer than six employees in Cameroon, Ghana, Kenya and Zimbabwe.

\footnotetext{
4 See Mansell-Carstens (1995) for a comprehensive review of the evidence and literature on informal finance, and Straub (2005) for a discussion of the role of informal finance in economies with bad institutions.

5 These data were collected by the Centre for the Study of African Economies via surveys between 1992 and 1998. In these data, the capital stock is the resale value of all structures, equipment and other fixed assets as estimated by the respondent in each firm.
} 
Informal employers also tend to operate on a much smaller scale than formal producers. Fortin et al. (1997) report that 90 per cent of all informal jobs (defined as jobs in establishments that not legally registered) come from units of production with fewer than six employees in Cameroon. In the private formal sector, that fraction is only 31 per cent. Table 1 illustrates the marked scale difference between formal and informal production with data for Buenos Aires and its suburbs drawn from Argentina's permanent household survey between 1993 and 1995. In these calculations, we restrict our attention to employees between the ages of 16 and 65 who have exactly one occupation. We classify workers as informally employed if they fail to receive social security coverage in the form of pension contributions and unemployment insurance, two benefits mandated by Argentina's labour laws. 6 As in most developing economies, small establishments account for a significantly higher fraction of employment in the informal sector than in the formal sector in Argentina.

Table 1: Individual and job characteristics of formal and informal sector employees: Buenos Aires and its suburbs

\begin{tabular}{lcccccc}
\hline & \multicolumn{2}{c}{1993} & \multicolumn{2}{c}{1994} & \multicolumn{2}{c}{1995} \\
\cline { 2 - 7 } & Formal & Informal & Formal & Informal & Formal & Informal \\
\cline { 2 - 7 } Establishment size (employees) & & & & & & \\
5 or fewer & 0.129 & 0.598 & 0.153 & 0.590 & 0.145 & 0.638 \\
6 to 25 & 0.278 & 0.242 & 0.273 & 0.265 & 0.279 & 0.242 \\
26 to 50 & 0.161 & 0.054 & 0.148 & 0.055 & 0.138 & 0.030 \\
51 to 100 & 0.122 & 0.043 & 0.128 & 0.040 & 0.133 & 0.026 \\
101 to 500 & 0.175 & 0.040 & 0.167 & 0.030 & 0.188 & 0.043 \\
More than 501 & 0.136 & 0.022 & 0.131 & 0.021 & 0.117 & 0.020 \\
Average age & 37.22 & 33.42 & 37.00 & 33.01 & 37.30 & 33.22 \\
Education & & & & & & \\
None & 0.004 & 0.006 & 0.003 & 0.010 & 0.003 & 0.009 \\
Primary & 0.337 & 0.491 & 0.324 & 0.488 & 0.351 & 0.485 \\
High-school & 0.429 & 0.378 & 0.431 & 0.389 & 0.386 & 0.367 \\
Superior & 0.058 & 0.033 & 0.074 & 0.024 & 0.077 & 0.027 \\
University & 0.171 & 0.093 & 0.168 & 0.089 & 0.183 & 0.113 \\
Hourly wages & 4.514 & 3.487 & 4.750 & 3.710 & 4.591 & 3.360 \\
Observations & 2806 & 1780 & 3032 & 1668 & 2965 & 1634 \\
\hline
\end{tabular}

Source: Argentina's Permanent Household Survey and Pratap and Quintin (2006). Entries give the fraction of employees in each category. Age is measured in years. Hourly wages are in 1993 pesos and corrected for Christmas bonuses.

The correlation between scale and formality is so strong that many studies simply equate informality with small scale production, a definition that has the virtue of being easy to implement, overly simplistic as it may be. This correlation also makes the importance of informal activities a natural explanation for the fact that small firms account for a much higher fraction of employment in developing nations than they do in

\footnotetext{
6 Pratap and Quintin (2006) discuss these data in detail.
} 
industrialized nations-see Tybout (2000) for a discussion. Many authors (see for example Rauch 1991; de Soto 1989; Gauthier and Gersovitz 1997) argue that the prevalence of small firms in developing nations is a response to the excessive regulations and taxes which large firms must bear.

\subsection{Formal and informal workers}

The distribution of employee characteristics also differs greatly across sectors. Among other differences, formal workers tend to be more educated, older and earn more than their informally employed counterparts as illustrated in Table 1 with data from Argentina's permanent household survey. Given that formal workers tend to have more experience and education than other workers, it is not surprising that hourly wages are higher in the formal sector than in the informal sector. A question that generates much debate is whether observable differences in worker characteristics can account for differences in earnings across sectors. The conventional view is that they cannot: formal workers, it is often suggested, earn more than observably similar informal sector workers. This view is supported by a number of empirical studies that find that some earnings-relevant characteristics of workers are better rewarded in the formal sector.7

However, as pointed out by Heckman and Hotz (1986), the fact that parametric estimates of earnings functions differ across sectors does not constitute compelling evidence that labour markets are segmented along formal/informal lines in developing nations. Earnings functions can differ in equilibrium if labour markets are weakly competitive, with heterogenous workers choosing the sector where their productivity is higher (Rosen 1978). 8 Earnings functions may also differ if individual skills are bundled (Heckman and Scheinkman 1987). Furthermore, much of the empirical work uses OLS techniques which may be biased by the endogeneity of sector choice. Pratap and Quintin (2006) show that in addition to constituting a weak test of segmentation, parametric evidence that a significant formal sector premium exists may be fragile. Standard tests applied to the data summarized in Table 1 suggest that a significant formal premium exists in Buenos Aires. But flexible semi-parametric estimation techniques applied to the same data yield no evidence that formal workers earn more than their observably similar informal counterparts.

Several studies of labour markets in developing nations emphasize the role of trade unions - see Alby et al. (2005) for a review of the literature on the effect of unionization in African countries. In many nations, particularly in the manufacturing sector, trade

7 See for example Mazumdar (1981) for Malaysia, Heckman and Hotz (1986) for Panama, Roberts (1989) for Guadalajara, Mexico, Pradhan and van Soest (1995) for Bolivia, Tansel (1999) for Turkey and Gong and van Soest (2001) for Mexico.

8 This is illustrated by Magnac (1991) who estimates a structural model of earnings and sector choices with Columbian data. He finds that earnings functions differ across sectors, but finds no evidence that moving across sectors is costly. 
unions, employers and the government negotiate industry-wide collective bargaining agreements which impose legal constraints on earnings and other aspects of labour contracts. In practice however, many workers (as a result of improper enforcement or the presence of various loopholes) do not receive the protection of unions and the dominant view (articulated by Mazumdar 1975) is that these workers must accept inferior pay and working conditions. However, while some studies find a positive effect of union membership on wages, many others find no such effect. In fact (see Alby et al. 2005) some studies find that union members tend to earn less than other, observably similar workers. 9

In summary, the existing evidence on whether labour markets are segmented along formal/informal lines in developing nations is mixed, at best. Not coincidentally, many recent models of the informal sector do not appeal to any segmentation arguments.

\section{Theories}

This section describes how models of informal economic activities have evolved over the years and evaluates the consistency of existing models with the facts we documented in Section 2. While we endeavor to mention as many of the many important contributions made in this area in the past half-century as possible, our main goal is for our literature review to be representative. Thomas (1992) provides a more comprehensive review of early work.

The notion that labour markets may be dualistic in developing nations dates back at least to the work of Lewis (1954) who expresses the view that the rural sector constitutes a stock of potential workers for the urban, formal sector where jobs pay higher wages. This view is formalized in the model of Harris and Todaro (1970) where urban wages are assumed higher than rural wages. Rural workers who choose to search urban jobs run the risk of becoming unemployed. In equilibrium, the mass of workers who choose to search is such that expected wages are equated across sectors. Fields (1975) expands on the Harris-Todaro model by assuming that urban workers can choose to become informally employed rather than search for higher paying formal jobs.

The seminal paper of Rauch (1991) marks the next major break in the modeling of informal economic activities. The model builds on Lucas' (1978) span-of-control model in which agents are endowed with different managerial ability levels. Agents can operate a strictly concave technology that transforms labour into the consumption good either in the formal sector or in the informal sector. Agents who choose to operate informally can choose to pay workers below the minimum wage, but they are constrained to operate below a certain detection threshold. This formalizes the view articulated by de Soto (1989) that producers in developing nations weigh the regulatory

9 See Alby et al. (2005) for a list of potential explanations for these findings. 
costs of operating formally against the benefits, in this case the ability to operate on a more efficient scale. This yields a model that is conceptually consistent with the correlation between the regulatory burden and the importance of informal activities and can replicate many salient aspects of the organization of production in developing nations. For instance, it provides an explanation for the fact that firms tend to be either very small or very large in those nations (a phenomenon known as the 'missing middle' in the economic development literature.)

In addition, Rauch's competitive equilibrium approach is a framework within which one can analyze the effects of various public policies on welfare, the tax base and the size of the informal sector taking into account general equilibrium effects (see Rauch 1991 for instance, for a discussion of the general equilibrium effects of changes in the minimum wage on the size of the informal sector.) The computable general equilibrium exercise of Fortin et al. (1997) constitutes perhaps the best illustration of the value of Rauch's framework for thinking about the effects of public policy choices.

Rauch (1991) emphasizes the fact that like traditional dualistic models, his model predicts that labour markets are segmented along formal/informal lines. Formally employed workers earn more than similar workers who are unable to find formal jobs. But his framework (together with de Soto's thought-provoking 1989 monograph) also paves the way for a drastic change in the perception of informal activities. In recent papers, the informal sector is most often modeled as the optimal, rational response of economic units (producers) to government-induced distortions rather than the disadvantaged end of dualistic labour markets.

Loayza (1996) illustrates this view by describing a model where labour-market segmentation plays no role. Producers can choose to avoid taxation but must then bear an exogenous cost of informality. Similarly, Sarte (2000) and Choi and Thum (2005) describe environments where the option to operate informally mitigates the distortions introduced by a rent-seeking bureaucracy.10 In Dessy and Pallage (2003), the productivity differential between the formal and the informal sector depends on the amount of taxes levied which makes the emergence of economies with high tax rates and large informal sectors endogenous.

Quintin (2000) and Antunes and Cavalcanti (2006) explicitly model the cost of informality as the lack of access to contract enforcement and quantify the effects of the tax burden and limited enforcement on the size of the informal sector via calibrated numerical simulations.11 Straub (2005) studies the impact of limited enforcement on informal activities in a model that explicitly considers the role and quality of informal

10 Marcouiller and Young (1995) model the informal sector as a way to avoid 'exploitation' by the state.

11 Antunes and Cavalcanti (2006) also quantify the importance of regulation costs for the size of the informal sector. 
credit mechanisms. Ihrig and Moe (2004) quantify the importance of various aspects of tax policy on the size of the informal sector.

Given the lack of compelling evidence that labour markets are segmented along formal/informal lines in developing nations, the fact that many recent models of the informal sector require no explicit barriers to labour mobility may be welcome progress. 12 However, an important question to ask is whether those models can replicate key features of labour markets in those countries. As documented in the previous section, workers employed in the formal sector tend to be more educated, more experienced and earn more than informally employed workers. If labour markets are integrated, why does the distribution of worker characteristics differ systematically across sectors? Amaral and Quintin (2006) propose an answer to this question, which we discuss in greater detail in the next section. Because they have limited access to outside sources of finance, informal producers may be constrained to substitute unskilled labour for physical capital. In other words, segmentation arguments are not necessary to account at least qualitatively for salient features of labour markets in developing nations.

The theoretical debate over whether a satisfactory model of informal activities should assume or imply some wage segmentation has important implications for policy. One natural policy response to wage segmentation is to introduce a formal sector wage subsidy_see Ray (1997: chapter 10) for a discussion. If labour markets are approximately integrated however, such a subsidy could have adverse effects on welfare and net tax revenues. If wage differentials across sectors reflect primarily productivity differentials, policy that aim solely at reducing the size of the informal sector are likely to be a poor substitute (at best) for direct investments in education or investments in the quality of formal institutions. Regardless of the outcome of the debate over segmentation, modern theories of informal economic activities suggest explanations for many salient features of the organization of production in developing countries. We make this point formally in the next section.

\section{A model}

We now outline a simple model that contains many of the ingredients of recent models of the informal sector and provides potential explanations for the facts we documented in Section 2.

As in Rauch (1991), the model is a general equilibrium model where producers select a sector in which to operate given the economy's institutional features. As in Loayza (1996), Sarte (2000), Quintin (2000), Straub (2005) and Amaral and Quintin (2006)

12 Most models continue to assume entry costs into the formal sector for producers to reflect for instance the cost of legal registration—see, for instance, Straub (2005). 
producers who choose to operate formally benefit from better institutions but they bear a regulatory cost. Specifically, we assume that contract enforcement is better in the formal sector but that formal producers need to pay taxes. This creates a tradeoff between access to formal sources of outside financing and the burden of taxation. The model, therefore, is consistent with the empirical link between the tax burden, the quality of formal institutions and the importance of informal economic activities. Clearly, it is also consistent with the fact that finance is scarce in the informal sector.

A key difference between the framework we outline below and many alternative models of the informal sector-including the models of Fields (1975) and Rauch (1991) - is the fact that labour markets are integrated. Workers can move between sectors at no cost and the value of workers' marginal product is equated across sectors. As we mentioned in the previous section, a natural question is whether the model can account for the fact that formal workers tend to be more educated and earn more than informal workers when labour markets are fully competitive. We will argue that it can under the standard assumption that capital and skill are complementary.

Consider then a static economy where agents are endowed with quantity $a>0$ of physical capital and a level $z>0$ of managerial ability. We assume that all agents are born with the same endowment of capital but that managerial talent varies across agents. We also assume that the distribution of managerial ability is continuous. Agents of ability $z>0$ can choose to become workers in which case they earn an endogenously determined wage $w$ or can instead choose to operate a technology that transforms inputs $(k, n) \geq(0,0)$ of physical capital and labour into quantity $z k^{\alpha_{k}} n^{\alpha_{n}}$ of the consumption good where $\alpha_{k}, \alpha_{n}>0$ and $\alpha_{n}+\alpha_{k}<1$.

Managers can self-finance the capital they use in production, but they can also borrow some capital from an intermediary that can borrow and lend without bound at exogenous rate $r>0$. Assuming that $r$ is exogenous simplifies this algebra. One can motivate this assumption by supposing that the economy under study is small and open or, alternatively, that the intermediary has access to a storage technology.

Our key assumption is that the market for loans is imperfect. Specifically, managers who borrow some capital can choose to default on the payment they owe the intermediary. In the formal sector, default carries a cost equal to fraction $\eta>0$ of the manager's income while in the informal sector, default carries no cost. This will imply that all production is self-financed in the informal sector. These assumptions formalize the fact that informal employers have limited access to formal means of contract enforcement in a simple fashion. ${ }^{13}$ On the other hand, we assume that managers who

\footnotetext{
${ }^{13}$ This contractual framework resembles the one described by Banerjee and Newman (1993). One could also generate endogenous borrowing constraints by assuming that informal assets are 'dead' in the sense of de Soto (2000), that is that they cannot be used as collateral. In fact, any friction that limits informal producers' access to finance should yield results similar to ours.
} 
operate in the formal sector must pay fraction $\tau$ of their net income as taxes, while informal managers can avoid taxation at no cost.

Given these institutional features, consider an agent of talent $z>0$ who chooses to become a manager in the formal sector and let $w$ be the price of labour. ${ }^{14}$ Let $k$ be the quantity of capital with which the agent operates and $s$ be the amount she uses as collateral for her loan. ${ }^{15}$ Then $d=k-s$ is the net (uncollateralized) capital they borrow from the intermediary. The maximum net income the manager can generate is given by:

$$
\begin{aligned}
V(z, \tau, \eta) & =(1-\tau) \max _{n \geq 0, s \leq a, d \geq 0}\left[z(s+d)^{\alpha_{k}} n^{\alpha_{n}}-(s+d)(1+r)-n w\right] \\
& =(1-\tau) \max _{s \leq a, d \geq 0}\left[A(w) z^{\frac{1}{1-\alpha_{n}}}(s+d)^{\theta}-(s+d)(1+r)\right]
\end{aligned}
$$

subject to the following no-default constraint:

$$
a(1+r)+(1-\tau)\left[A(w) z^{\frac{1}{1-\alpha_{n}}}(s+d)^{\theta}-(s+d)(1+r)\right] \geq(1-\eta)(1-\tau) A(w) z^{\frac{1}{1-\alpha_{n}}}(s+d)^{\theta}+(a-s)(1+r)
$$

where $A(w)=\left(\frac{1}{\alpha_{n}}-1\right) \alpha_{n}^{\frac{1}{1-\alpha_{n}}} W^{\frac{-\alpha_{n}}{1-\alpha_{n}}}$ and $\theta=\frac{\alpha_{k}}{1-\alpha_{n}}<1$

The constraint says that loan contracts must be incentive compatible. The left-hand side of the constraint is the end-of period income the manager receives if she chooses to honor her debt, while the right-hand side is her income if she defaults. When she defaults, she economizes on gross payment $(s+d)(1+r)$ she owes the intermediary, but she loses the accrued value $s(1+r)$ of her collateral, and fraction $\eta$ of her net income as default cost. This formulation of the incentive compatibility constraint assumes that agents who default in the formal sector must pay taxes. Assuming that agents who default on their loan also manage to default on their taxes would not change any of our qualitative results. Note that this statement of the problem also assumes that the intermediary behaves competitively. Among contracts that are incentive compatible and cover the intermediary's opportunity cost of capital, the contract most favourable to the manager prevails.

Solutions to the constrained contracting problem are easy to characterize. Note first that given $z>0$ there is a unique scale $k^{*}(z)$ of operation such that the marginal product of capital is $1+r$. Absent contractual imperfections (when $\eta=1$ ) all formal agents operate at this optimal scale. But when $\eta<1$, one can show (see Amaral and Quintin 2006) that given $z>0$ there exists an asset threshold $a^{*}(z ; \eta, \tau)$ such that agents are constrained if

\footnotetext{
${ }^{14}$ Because we assume no barriers to labour mobility, the price of labour must be the same in the two sectors.

${ }^{15}$ Assuming that the intermediary can seize all of the manager's asset in the event of default would not alter the analysis in any way since as we argue below it is optimal for all constrained agents to choose $s=a$.
} 
and only if $a<a^{*}(z ; \eta, \tau)$. Furthermore, constrained managers use their entire assets as collateral (they set $s=a$ ) since the marginal product of capital exceeds $(1+r)$ in constrained establishments. Finally, the loan size rises with managerial talent because raising $z$ weakens the incentive compatibility constraint.

A manager chooses to operate formally when $V(z, \tau, \eta) \geq V(z, 0,0)$ and agents become workers when $\max \{V(z, \tau, \eta), V(z, 0,0)\}<w$. In particular, it is agents of low managerial ability who choose to become workers. The choice of sector is also characterized by a talent threshold. This is because agents of high talent can manage a large quantity of resources more effectively hence stand to benefit the most from access to outside finance. Formally: ${ }^{16}$

Lemma 1: Given $w$, there exists $\underline{z}$ and $\bar{z}$ such that agents of ability $z$ become workers if $z<\underline{z}$, informal managers if $z \in(\underline{z}, \bar{z})$ and formal managers if $z \in(\bar{z}, 1]$.

Proof. Assume that $z$ is such that $V(z ; \tau, \eta)=V(z, 0,0)$. Then $a<k^{*}(z)$ since otherwise the agent has no need for finance and would be better off avoiding taxation. Hence:

$V(z, 0,0)=A(w) z^{\frac{1}{1-\alpha_{n}}} a^{\theta}-a(1+r)$.

In the formal sector on the other hand:

$V(z, \tau, \eta)=(1-\tau)\left[A(w) z^{\frac{1}{1-\alpha_{n}}}(a+d(z))^{\theta}-(a+d(z))(1+r)\right]$

where $d(z)$ is the intermediary's net advance. ${ }^{17}$

We wish to argue that $V_{1}(z ; \tau, \eta)>V_{1}(z, 0,0)$. This will imply that $V(\bullet ; \tau, \eta)$ can only cross $V(\bullet ; 0,0)$ from below and complete the proof. Inspection of the expressions for those two functions and the fact that $d$ rises with $z$ shows that $V_{1}(z ; \tau, \eta)>V_{1}(z, 0,0)$ if $a^{\theta}<(1-\tau)(a+d(z))^{\theta}$. To show that this last condition holds, note that $V(z, 0,0)=V(z ; \tau, \eta)$ means that:

$$
\begin{gathered}
A(w) z^{\frac{1}{1-\alpha_{n}}} a^{\theta}-a(1+r)=(1-\tau)\left[A(w) z^{\frac{1}{1-\alpha_{n}}}(a+d(z))^{\theta}-(a+d(z))(1+r)\right] \\
\Longleftrightarrow \tau\left[A(w) z^{\frac{1}{1-\alpha_{n}}} a^{\theta}-a(1+r)\right]=(1-\tau)\left[A(w) z^{\frac{1}{1-\alpha_{n}}}(a+d(z))^{\theta}-A(w) z^{\frac{1}{1-\alpha_{n}}} a^{\theta}-d(z)(1+r)\right]
\end{gathered}
$$

\footnotetext{
${ }^{16}$ The negligible mass of agents whose talent level coincides with one of the thresholds are indifferent between two occupations.

${ }^{17}$ Because $a<k^{*}(z)$, one can argue that an optimal contract exists for formal managers of ability $Z$ such that $s=a$.
} 
In turn, letting $\delta \equiv \theta A(w) z^{\frac{1}{1-\alpha_{n}}} a^{\theta-1}$ (that is, $\delta$ denotes the marginal product of capital at $a$ ), standard properties of strictly concave functions and some algebra imply:

$$
\begin{aligned}
\tau a(\delta-(1+r)) & <\tau\left[A(w) z^{\frac{1}{1-\alpha_{n}}} a^{\theta}-a(1+r)\right] \\
& =(1-\tau)\left[A(w) z^{\frac{1}{1-\alpha_{n}}}(a+d(z))^{\theta}-A(w) z^{\frac{1}{1-\alpha_{n}}} a^{\theta}-d(z)(1+r)\right] \\
& <(1-\tau) d(z)(\delta-(1+r))
\end{aligned}
$$

so that $(1-\tau) d(z)>\tau a$ since $\delta-(1+r)>0$ for constrained managers. Then, $V(z ; \tau, \eta)=V(z, 0,0)$ implies $(1-\tau)(a+d(z))^{\theta}>a^{\theta}$, as needed.

Optimal policies are then fully described by the two ability thresholds and by the maximum incentive compatible loan formal managers can obtain from the intermediary. An equilibrium in this environment is a value for the wage rate such that given optimal policies the labour market clears. Standard arguments imply that an equilibrium exists in this environment.

It should also be clear that the equilibrium informal share of employment, capital and output is increasing in the tax rate and/or declining in the quality of contract enforcement in the formal sector. When $\eta=0$ for instance, one easily shows that $d(z)=0$ for all $z \geq 0$ in equilibrium. Since access to finance is the only potential benefit associated with opting for the formal sector in this model, all agents choose to operate informally when $\eta=0$. When $\eta=1$ on the other hand all formal agents are unconstrained and the corresponding profit increase can be significant for agents of high managerial ability.

The model is thus consistent with the empirical link between the tax burden, institutional quality and the size of the informal sector. It also predicts that the organization of production should differ across sectors, as our next result states:

Proposition 2: In equilibrium, formal managers employ more capital and workers and are more productive in total factor terms than informal managers.

Proof. Lemma 1 implies directly that formal managers are more productive than informal managers. In turn, since raising $z$ weakens the incentive compatibility constraint, this implies that formal managers employ more capital than informal managers, and that they employ more workers.

Therefore, the model correctly predicts that the informal sector should emphasize smallscale, self-financed production. One can also show that as long as the enforcement gap between the two sectors is large enough, formal managers operate at a higher capitallabour ratio than informal managers. This yields a possible explanation for the fact that the informal sector emphasizes unskilled labour given the well-documented 
complementarity between skill and physical capital. Because they tend to be more borrowing-constrained, informal employers choose to substitute unskilled labour for physical capital—see Amaral and Quintin (2006) for a formalization of this idea. In other words, despite the fact that labour markets are assumed to be completely integrated in our model, the distribution of worker characteristics can differ greatly in equilibrium. The model also provides a framework to think about the potential link between wealth inequality, output and the importance of informal economic activities. A redistribution of wealth towards more talented managers could raise aggregate output and consumption by concentrating resources in the hands of the economy's most productive agents. With some ex-post redistribution of income (a challenging prospect, admittedly, in economies with poor quality institutions) welfare could increase.

Note however that this redistribution of wealth would have ambiguous effects on the size of the informal sector and the tax base. On the one hand, wealthier agents can borrow more capital in the formal sector (raising $s$ weakens the incentive-compatibility constraint formal managers face) but they also have less of a need for outside finance, all else equal. Of course, managerial talent is probably difficult to observe or verify which makes talent-based redistribution difficult to implement in practice.18

However, even a wealth-redistribution scheme that is orthogonal to managerial talent could have positive effects on output. Indeed, in a version of the model we have outlined with exogenous wealth inequality, occupation profiles no longer depend solely on talent, they also potentially depend on wealth. Wealthier agents, all else equal, are more likely to become managers while more talented but less wealthy agents are forced to become workers. Making wealth more equal mitigates this source of inefficiency. ${ }^{19}$

While qualitatively promising however, the quantitative impact of wealth redistribution schemes could be small. For instance, Quintin (2000) finds that in the context of a dynamic general equilibrium version of the model presented here, even drastic wealth redistribution schemes do little to alleviate the impact of limited enforcement. Even when there is little or no wealth inequality, agents need access to outside sources of finance to operate on an efficient scale. Wealth redistribution schemes, therefore, may be a poor substitute for dealing directly with obstacles to the process of financial intermediation.

The environment we described in this section also suggests that growth naturally brings about drastic changes in the organization of production and the importance of informal

18 A practical substitute for talent-based redistribution in this environment is a subsidy to formal managers. Because talented managers self-select into the formal sector, more talented managers are more likely to take advantage of the subsidy. Another benefit associated with this scheme is that it has a positive impact on the tax base.

${ }^{19}$ Naturally and by the same logic, a wealth redistribution scheme that is negatively correlated with talent could have adverse effects on output and productivity. 
activities. Assume that the distribution of managerial productivity shifts to the right over time. The equilibrium wage rate (the opportunity cost of self-employment) then rises over time, which, under some assumptions on the shape of technological opportunities, could lead ever more people to choose to work for others rather than become selfemployed. Therefore we should expect self-employment to fall as an economy develops, and the average scale of operation to rise, making access to formal sources of finance more valuable. This process is illustrated by Gollin (2000) who also argues that this broad pattern of economic development is borne out by the relevant evidence. ${ }^{20}$ Finally, the model's prediction that formal production is more capital-intensive than informal production (a prediction that is borne out by the evidence discussed in Section 2) has important implications for the measurement of informal sector assets, an issue to which we now turn.

\section{Measuring informal sector assets}

While estimates of the output or employment size of the informal sector exist for a large cross-section of nations, estimates of the size of the assets in the informal sector are much less common. One important exception is de Soto (2000) whose rough estimates of the stock of informal capital confirm the strong belief among development economists that massive amounts of wealth are in the informal sector in developing nations. $^{21}$

De Soto's estimates are staggering. He calculates for instance that 'the total value of real estate held but not legally owned by the poor' in developing nations approaches ten trillion dollars, which is 'about twice as much as the total circulating US money supply.' According to de Soto, the stock of informal wealth is many times greater than the stock of recorded foreign investment in many nations. de Soto's estimates are rough, but they make it clear that omitting informal assets in wealth measurement exercises could lead to highly biased results—-see Davies and Shorrocks (2005) for a discussion.

How should one go about measuring informal wealth? Estimates of the output and employment size of the informal sector can in principle provide an upper bound for the stock of informal capital since all evidence is that informal production is less capitalintensive than formal production. The resulting upper bound is quite imprecise however not only because informal output and employment measures are themselves imprecise, but also because the capital intensity of production differs greatly across sectors. Because they have very limited access to outside finance, informal producers are constrained to substitute labour for capital, a theoretical prediction which is strongly borne out by the available evidence.

\footnotetext{
${ }^{20}$ See also Banerjee and Newman (1993).

${ }^{21}$ Woodruff (2001) discusses and questions the quality of de Soto's estimates. He argues that de Soto vastly exaggerates the magnitude of informal assets but acknowledges that even conservative estimates of the asset-size of the informal sector are 'quite large.'
} 
To illustrate the potential importance of capital-intensity differences across sectors, consider an economy where the stock of capital in the informal sector is $K^{I}$ while the formal stock of capital is $K^{F}$. Similarly, denote informal employment by $E^{I}$ and formal employment by $E^{F}$. The informal share of physical capital is then given by:

$$
\frac{K^{I}}{K^{I}+K^{F}}=\frac{E^{I} \frac{K^{I}}{E^{I}}}{E^{I} \frac{K^{I}}{E^{I}}+E^{F} \frac{K^{F}}{E^{F}}}=\frac{s^{I}}{s^{I}+\left(1-s^{I}\right)\left(\frac{K^{F}}{E^{F}} / \frac{K^{I}}{E^{I}}\right)}
$$

where $s^{I}=\frac{E^{I}}{E^{I}+E^{F}}$ is the informal share of employment and $\left(\frac{K^{F}}{E^{F}} / \frac{K^{I}}{E^{I}}\right)$ is the quotient of the capital-employment ratio in the formal sector and the capital-employment ratio in the informal sector. In the case of Cameroon for instance, ILO (2003: table 7, section 2) reports that unincorporated, unregistered enterprises with 10 employees or fewer account for roughly 60 per cent of employment. The data presented by Soderbom and Teal (2000) suggest on the other hand that large manufacturing firms are roughly three times more capital-intensive than micro firms in Cameroon. Using these numbers as approximations for $s^{I}$ and $\left(\frac{K^{F}}{E^{F}} / \frac{K^{I}}{E^{I}}\right)$ in Cameroon yields an asset share of roughly one third. Because informal production is more labour intensive than formal production, the informal sector share of the capital stock is noticeably below the informal share of output and employment. However, even after large capital-intensity corrections, the asset share of the informal sector is likely to remain far from negligible in low income nations.

While indicative, indirect calculations along these lines can only yield rough estimates of the asset size of the informal sector. Properly accounting for informal wealth requires some direct measurement of informal gross fixed capital formation. Standard measures of the stock of physical capital use the perpetual inventory method applied to investment flows available by broad category in national accounts data. Therefore, estimates of the aggregate stock of physical capital reflect the importance of informal activities only if informal gross fixed capital formation is properly represented in national accounts. To evaluate the extent to which this condition is met, it is important to first recognize that, in theory, informal investment is included in gross fixed capital formation series. In accordance with 1993 systems of national accounts standards, national accountants should include in their calculations activities that are 'underground, illegal, informal or undertaken by households for their own final use'. In particular, informal does not mean unmeasured. However, given their nature, informal activities are measured with significant error and bias.

Macroeconomic models such as those described in Section 2 are one of the primary tools national accountants in developing countries use to gauge the importance of informal activities. In its handbook devoted to the problem of measuring 'non-observed' economic activity, the OECD (2002) sharply criticizes this approach. They express a 
strong preference for the 'transparent' use of 'all available data' to directly measure non-observed activities and encourage national accountants to use data from 'a variety of sources' on a 'careful, case-by-case basis ... These data are capable of producing much more accurate estimates of GDP and its components than macro-models can ever do. ${ }^{22}$

In practice, national accountants do supplement macroeconomic estimates of the size of the informal sector with various ad-hoc techniques. In many nations, non-observed gross fixed capital formation is estimated using a commodity flow approach. Independent data on material use (with markups designed to approximately correct for under-recording where appropriate) and input-output assumptions are used to arrive at comprehensive capital formation measures. The goal is to try and correct for the fact that establishment surveys (the source of a big part of investment data in most countries) are subject to much measurement error. While respondents have no obvious incentive to underreport investment, small, young establishments are likely to be under-sampled in those surveys. As is well-known, developing nations emphasize small-scale production which makes the problem of tracking down small, transient establishments particularly acute.

Despite the efforts expended by national accountants, informal sectors clearly add noise to available measures of the physical capital stock. Wealth inequality measures based on standard methods and data could be overstated because of the likely magnitude of error in the measurement of informal production and investment, and because a significant part of these activities are not properly taken into account. The only solution to these measurement issues is to improve the precision of national accounting practices. Much progress has been made in this area over the past decade which bodes well for our ability to eventually arrive at better measures of aggregate wealth and worldwide wealth inequality. These measurement issues notwithstanding, there is little doubt that a very large fraction of wealth is held informally in most developing nations. This, in turn, has important consequences for the growth prospects of these nations.

Informal assets are much more difficult to leverage into loans than assets that carry proper titles, a fact de Soto (2000) describes as 'the major stumbling block that keeps the rest of the world from benefiting from capitalism'. Because it is difficult for banks to enforce the stipulations of loans contracts (which includes the collection of collateral in the event of default), lending cannot be supported in the informal sector. According to de Soto (2000) the reason why informal assets are not treated as proper collateral for loans is that property rights over these assets are not clearly defined and legally recorded. As a result, informal assets are 'dead capital' because 'they cannot be turned

\footnotetext{
${ }^{22}$ The strong preference on the part of economists for macro-models is easy to understand however. A unified methodology is necessary for cross-country comparisons. The use of macro estimates does not pre-suppose the understanding of 'case-by-case' procedure choices made by national accountants at all stages of the data collection process.
} 
into capital, cannot be traded outside of narrow local circles where people know and trust each other, cannot be used as collateral for a loan, and cannot be used as a share against and investment'. The most obvious implication of these observations is that titling programs have the potential to unleash vast amounts of under-utilized resources in developing nations by allowing households to pursue previously untapped investment opportunities.

Yet, as Woodruff (2001) points out, titling programs have produced disappointing results in many cases. Woodruff views this as evidence that titling programs can only be successful as part of a broad set of reforms designed to improve the functioning of institutions. Quite obviously, a better definition of property rights, in and of itself, is not likely to have much impact in nations where formal means of contract enforcement are weak. The broad challenge is to create an institutional environment where informal assets, both physical and human, can be directed to their most productive use.

\section{Conclusion}

Research on the nature, determinants and consequences of informal activities in developing nations has yielded a number of important insights. Among other empirical regularities, the importance of informal activities is highly correlated with a nation's level of economic development and the quality of its institutions. Furthermore, the informal sector emphasizes small-scale, unskilled-labour intensive, self-financed activities. Modern models of the informal sectors are consistent with these facts and provide natural frameworks for evaluating the potential consequences of pro-growth policies in nations with large informal sectors. ${ }^{23}$

For instance, competition-enhancing reforms and efforts to reduce the burden of regulation can have a big impact on the size of the formal sector as the economy adjusts to these institutional changes and resources move across sectors. The welfare consequences of these shocks to formal employment depend in part on the degree of integration between the formal and the informal labour market. If the informal sector is best viewed as the disadvantaged end of dualistic labour markets, transitional or permanent reductions in formal employment could induce large welfare losses. On the other hand, precisely because it absorbs some of the cyclical and transitional variations in formal employment, the informal sector may in fact help mitigate the short-run impact of reforms. ${ }^{24}$

\footnotetext{
${ }^{23}$ The impact of a variety of reforms on the importance of informal activities and on poverty was the object of a 2004 conference organized by the World Institute for Development Economics Research. A summary of the conference proceedings is available at: http://www.wider.unu.edu/conference/conference2004-2/conference2004-2.htm.

${ }^{24}$ Similarly, recessions triggered for instance by financial crises in emerging nations lead to very large swings in the informal share of employment. This is evidence that workers accept lower paying jobs during downturns, but this also illustrates the key buffer role informal employment plays in those economies.
} 
Generally speaking, dualistic models provide a rationale for policies that aim directly at shifting more resources to the formal sector. If marginal products are not equated across sectors, increasing formal employment can reduce poverty and increase welfare. If, on the other hand, income differences across sectors reflect productivity differences and the two labour markets are well integrated, policies whose sole objective is to boost formal employment are unlikely to yield large welfare gains. In those models, reducing poverty requires investments in human capital, and broad pro-growth policies are more likely to benefit all workers. In summary, how best to model informal activities is not merely an academic question. It has important consequences for how best to design efforts to alleviate poverty in developing economies.

One area where much work remains to be done is the measurement of informal wealth. Estimates of the asset size of the informal sector are rare and imprecise when they exist. A satisfactory analysis of wealth inequality across households and across countries demands better data.

\section{References}

Alby, P., J. Azam, and S. Rospabe (2005). 'Labour Institutions, Labour Management Relations and Social Dialogue’, mimeo, World Bank: Washington DC.

Amaral, P., and E. Quintin (2006). 'A Competitive Model of the Informal Sector', Journal of Monetary Economics 53(7): 1541-53.

Antunes, A., and T. Cavalcanti (2006). 'Start Up Costs, Limited Enforcement, and the Hidden Economy’, European Economic Review (forthcoming).

Banerjee, A.V., and A.F. Newman, (1993). 'Occupational Choice and the Process of Development’, Journal of Political Economy 101(2): 274-98.

Botero, J., S. Djankov, R. La Porta, F. Lopez-de-Silanes, and A. Schleifer (2003). 'The Regulation of Labour', NBER Working Paper 9756, National Bureau of Economic Research: Cambridge MA.

Bromley, R.T. (1978). 'Introduction: The Urban Informal Sector: Why is it Worth Discussing?', World Development 6: 1033-9.

Castells, M., A. Portes, and L.A. Benton (1989). The Informal Economy: Studies in Advanced and Less Developed Countries, Johns Hopkins University Press: Baltimore.

Chickering, L.A. and M. Salahdine (eds) (1991). The Silent Revolution: The Informal Sector in Five Asian and Near Eastern Countries, ICS Press: San Francisco.

Choi, J.P. and M.P. Thum (2005). 'Corruption and the Shadow Economy,' International Economic Review 46: 817-36. 
Davies, J., and A. Shorrocks (2005). 'Wealth Holdings in Developing and Transition Economies', paper presented at the Luxembourg Wealth Study conference on Construction and Usage of Comparable Microdata on Wealth, 27-29 January, Perugia.

Dessy, S., and S. Pallage (2003). 'Taxes, Inequality and the Size of the Informal Sector', Journal of Development Economics 70: 225-33.

de Soto, H. (1989). The Other Path: The Economic Answer to Terrorism, Harper \& Row: New York.

de Soto, H. (2000). The Mystery of Capital: Why Capitalism Triumphs in the West and Fails Everywhere Else, Basic Books: New York.

Djankov, S., R. La Porta, F. Lopez-de-Silanes, and A. Schleifer (2002). 'The Regulation of Entry', Quarterly Journal of Economics 117: 1-37.

Fields, G.S. (1975). 'Rural-Urban Migration, Urban Unemployment and UnderDevelopment, and Job-Search Security in LDCs', Journal of Development Economics 2: 165-87.

Fortin, B., N. Marceau, and L. Savard (1997). 'Taxation, Wage Controls and the Informal Sector', Journal of Public Economics 66: 239-312.

Gauthier, B., and M. Gersowitz (1997). 'Revenue Erosion Through Tax Exemption and Evasion in Poor Countries’, Journal of Public Economics 64: 404-24.

Gollin, D. (2000). 'Nobody’s Business but My Own: Self Employment and Small Enterprise in Economic Development', mimeo, Williams College: Williamstown MA.

Gong, X., and A. van Soest (2001). 'Wage Differentials and Mobility in the Urban Labour Market: A Panel Data Analysis for Mexico’, IZA Discussion Paper 329, IZA: Bonn.

Harris, J.R. and M.P. Todaro (1970). 'Migration, Unemployment and Development: A Two-Sector Analysis’, American Economic Review 60: 126-42.

Hart, K. (1973). 'Informal Income Opportunities and Urban Employment in Ghana', Journal of Modern African Studies 11: 61-89.

Heckman, J.J., and V. Hotz (1986). 'An investigation of Labour Market Earnings of Panamanian Males’, Journal of Human Resources 21: 507-542.

Heckman, J.J., and J. Scheinkman (1987). 'The Importance of Bundling in a GormanLancaster Model of Earnings', Review of Economic Studies 54: 243-55.

Ihrig, J., and K. Moe (2004). 'Lurking in the Shadows: The Informal Sector and Government Policy’, Journal of Development Economics 73: 541-57. 
ILO (1972) 'Employment, Income and Equality: A Strategy for Increasing Productivity in Kenya’, International Labour Organization: Geneva.

ILO (2003). Key Indicators of the Labour Market, Routlege: New York.

Johnson, S., D. Kauffman and A. Shleifer (1997). 'The Unofficial Economy in Transition’, Brookings Papers on Economic Activity 2: 159-239.

Johnson S., D. Kauffman, and P. Zoido-Lobaton, (1998). 'Regulatory Discretion and the Unofficial Economy’, American Economic Association Papers and Proceedings 88: 387-92.

Lucas, R.E. (1978). 'On the Size Distribution of Business Firms', Bell Journal of Economics 9: 508-23.

Lewis, W.A. (1954). 'Economic Development with Unlimited Supplies of Labour', Manchester School 22: 139-91.

Loayza, N.V. (1996). 'The Economics of the Informal Sector: A Simple Model and Some Empirical Evidence from Latin America', Carnegie-Rochester Conference Series on Public Policy 45: 129-62.

Magnac, T. (1991). 'Segmented or Competitive Labour Markets', Econometrica 59: 165-87.

Maloney, W.F. (1999). 'Does Informality Imply Segmentation in Urban Labour Markets? Evidence from Sectoral Transitions in Mexico', World Bank Economic Review 13: 275-302.

Mansell-Carstens, C. (1995). Las Finanzas Populares en México, Centro de Estudios Monetarios Latinoamericanos, Editorial Milenio: Mexico City.

Marcouiller, D., and L. Young (1995). 'The Black Hole of Graft: The Predatory State and the Informal Economy', American Economic Review 85: 630-46.

Mazumdar, D. (1975). 'The Theory of Urban Employment in Less Developed Countries’, World Development 4: 655-79.

Mazumdar, D. (1981). The Urban Labour Market Income Distribution: A Study of Malaysia, Oxford University Press: Oxford.

OECD (2002). Measuring the Non-Observed Economy: A Handbook, Organization for Economic Co-operation and Development: Paris.

Paredes Cruzatt, P. (1987). 'Segmentacion del Mercado Laboural en Lima Metropolitana’, Planificacion del Mercado Laboural, Proyecto Per/85/007, Cuadernos de Informaciones: Lima.

Portes, A., M. Castells, and L.A. Benton (eds) (1989). The Informal Economy: Studies in Advanced and Less Developed Countries, Johns Hopkins University Press: Baltimore. 
Pradhan, M., and A. van Soest (1995). 'Formal and Informal Sector Employment in Urban Areas of Bolivia’, Labour Economics 2: 275-97.

Pratap, S., and E. Quintin (2006). 'Are Labour Markets Segmented in Developing Countries? A Semiparametric Approach', European Economic Review 50(7): 181741.

Quintin, E. (2000). 'Limited Enforcement and Economic Development', PhD dissertation, Univeristy of Minnesota.

Rauch, J.E. (1991). 'Modeling the Informal Sector Formally', Journal of Development Economics 35: 33-48.

Ray, D. (1997). Development Economics, Princeton University Press: New Jersey.

Roberts, B.R. (1989). 'Employment Structure, Life Cycle, and Life Chances: Formal and Informal Sectors in Guadalajara', in A. Portes, M. Castells, and L.A. Benton (eds), The Informal Economy: Studies in Advanced and Less Developed Countries, Johns Hopkins University Press: Baltimore.

Rosen, S. (1978). 'Substitution and Division of Labour', Economica 45: 235-50.

Schneider, F., and D.H. Enste (2000). 'Shadow Economies: Size, Causes, and Consequences', Journal of Economic Literature 38: 77-114.

Sarte, P.G. (2000). 'Informality and Rent-Seeking Bureaucracies in a Model of LongRun Growth', Journal of Monetary Economics 46: 173-97.

Sethuraman, S.V. (1981). 'The Urban Informal Sector in Developing Countries: Employment, Poverty and Environment', International Labour Organization: Geneva.

Soderbom, M., and F. Teal (2000). 'Skills, investment and exports from manufacturing firms in Africa', CSAE Working Paper 8, Centre for the Study of African Economies, University of Oxford: Oxford.

Straub, S. (2005). 'Informal Sector: The Credit Market Channel', Journal of Development Economics 78: 299-321.

Tansel, A. (1999). 'Formal versus Informal Sector Choice of Wage Earners and Their Wages in Turkey', Economic Research Forum Working Paper 9927.

Thomas, J.J. (1992). Informal Economic Activity, London School of Economics Handbooks in Economics, London School of Economics: London.

Tybout, J.R. (2000). 'Manufacturing Firms in Developing Countries: How Well Do They Do and Why?', Journal of Economic Literature 38: 11-44.

Weeks, J. (1975). 'Policies for Expanding Employment in the Informal Urban Sector of Developing Economies’, International Labour Review 111: 1-13. 
Wendorff., C. (1985). 'Sector Informal Urbano y Crisis Economica: Diagnostico y Alternativa de Politica', in N. Henriques and A. Ponce (eds), Lima: Poblacion, Trabajo y Politica, Pontifica Universidad Catolica del Peru: Lima.

Woodruff, C. (2001). 'Review of de Soto's “The Mystery of Capital”, Journal of Economic Literature 39(4): 1215-23. 